\title{
The Modern Drivers of Productivity
}

\author{
Francesco Venturini*
}

Current version: January 15, 2009

\begin{abstract}
Using country-level data, this paper investigates the determinants of productivity in emerging knowledge economies by estimating the spillovers associated with investment in Research \& Development (R\&D) and Information Technology (IT). The work illustrates that both forms of technicallyadvanced capital (R\&D and IT) matter for long-run TFP growth. Furthermore, by inspecting knowledge spillovers associated with either the domestic production or import penetration of high-tech (IT) goods, we show that the R\&D base of the domestic producers of IT assets is a fundamental driver of economic growth for the industrialized countries. In terms of TFP gains, a low degree of industry specialization in information technology can only partly be compensated by a country's trade openness, i.e. importing R\&Dintensive (IT) goods from abroad. This contrasts to what occurs for less technically-advanced (non-IT) productions, for which trade is an effective conduit for knowledge.
\end{abstract}

Keywords: Information Technology, Research \& Development, Spillovers, Trade, Productivity.

JEL classification: E22, F43, O32, O47.

${ }^{*}$ Department of Economics, Finance and Statistics, University of Perugia, Via Pascoli 20, 06123 Perugia (Italy). Tel.: +39 0755855291 . This is a revised version of the paper entitled 'Information Technology, Research \& Development, or both? What really drives a nation's productivity', Quaderno di Ricerca n. 321, Department of Economics, Polytechnic University of Marche (2008). 'The author wishes to thank Alessia Lo Turco, Nicola Matteucci, Jacques Mairesse, Andrea Presbitero, Jesus Rodriguez Lopez, Alessandro Sterlacchini and the seminar participants at Ancona, Bologna, EUKLEMS Final Conference (Groningen), 6th ZEW Conference on ICT (Mannheim). Joakim Westerlund is gratefully acknowledged for providing some codes used in the econometric analysis. Any error is solely responsibility of the author. 


\section{Introduction}

Technical change as outcome of intentional innovation activity is a crucial factor for the competitiveness of the modern industrialised economies. Research-based innovation $(R \& D)$ is considered one of the main sources of productivity, sizeably contributing to a nation's well-being over the long-run. Undoubtedly, one of the most extraordinary scientific achievements of the last decades are the advances made in the field of information technology (IT). IT is argued to be the key force behind the growth resurgence recently experienced by most countries, the US ahead.

Thus far, the majority of works have separately examined the growth impact of IT and R\&D, delivering a partial outline of the true drivers of TFP in the emerging knowledge societies. These two factors are in fact closely related, presenting some similarities (and even some discrepancies) that should not be ignored in both theoretical and empirical research. Firstly, they spur productivity by enabling knowledge dissemination (both R\&D and IT) or creating network externalities (mainly IT). Secondly, IT producers are the most intensively involved in knowledge generation, accounting for a large fraction of R\&D and patenting activity; R\&D-based innovation raises the efficiency of the IT-producing sector and, finally, its benefits accrue to all the purchasers of digital goods. Thirdly, the application of the new generations of computers and experimental technologies has enormously enhanced the productivity of research activity; at the top level, digital technologies have opened up new frontiers for science (genoma, high-temperature superconductors, etc.) and favored a faster circulation of ideas, as shown by the explosion of the scientific literature during the Internet age. Though, the complex relation between IT and R\&D makes the assessment of their productivity effects a particularly hard task, especially in the short-run when each of these factors is likely to reinforce the impact of the other. Over a long-term horizon, instead, their social returns appear more easily identifiable as the periods of learning, adjustment and patent protection come to an end.

With the view to identifying the drivers of productivity in the current technological age, this paper estimates spillovers from economy-wide investment in IT and R\&D by performing a cointegration analysis on a panel of OECD countries over the last quarter of century. The work is developed in four steps. Firstly, the elasticity of productivity to both forms of technological capital is estimated within a close-economy setup controlling for the major issues that may undermine the consistency of results. Secondly, we examine the industry sources of the within-country spillovers associated with $R \& D$, focussing on the role of knowledge generated by the IT-producing industry. Thirdly, the analysis is extended to an open-economy framework to trace the spillovers related to the international trade of IT goods. Finally, the last stage of the work studies the complementarity 
between IT and R\&D, cheking whether the spillovers of each type of technicallyadvanced capital are raised by the extent to which a country invests on the other type of assets.

Our evidence indicates that a strong specialization in IT production is either a key determinant of a nation's productivity or a crucial factor to compete on the global market. At the same time, IT capital turns out to provide additional TFP gains with respect to $\mathrm{R} \& \mathrm{D}$, probably due to its ability to generate network externalities or specific knowledge spillovers; therefore, investing in this special kind of tangible assets appears highly recommendable, even though it is unlikely to fully offset a country's de-specialization in high-tech (IT) productions. In line with earlier studies, international technology spillovers associated with R\&D of the non-IT sector are found to dominate those of domestic research; it confirms that, for relatively low-tech goods, trade is an effective channel for knowledge diffusion. On the other hand, R\&D embodied in imported IT goods alone is not able to stimulate productivity, but it does when recipient countries massively invest in IT capital; this finding suggests that the development of a wide digital infrastructure may be a crucial condition to absorb high-tech (IT-related) knowledge created abroad.

The outline of the paper is as follows. Section 2 draws both the theoretical and the empirical background of the work. Section 3 defines the analytical framework and discusses some econometric issues. Data description and summary statistics are provided in Section 4, while the econometric results are presented in Section 5. Finally, Section 6 reports some concluding remarks.

\section{Overview of related literature}

\subsection{Theoretical background}

In recent years, a great attention has been paid to the contribution of information technology to economic growth. An increasing effort has been devoted to formally describing the mechanism at the roots of this process. Venturini (2007) develops a growth model where the learning-by-doing associated with the usage of IT assets positively affects TFP growth along the equilibrium path. On the other hand, Vourvachaki (2006) endogenousizes the forces underlying the growth effect of information technology, that is assumed to depend on the R\&D effort of IT producers. Krusell (1998) has constructed a general model where R\&D is designed to improve the efficiency of new capital vintages, whose diffusion permanently stimulates economic growth. More recently, Ngai and Samaniego (2008) have developed a (multi-sector) endogenous growth framework that explicitly recognizes cross-industry heterogeneity in research intensity and TFP growth. Nonetheless, 
by assuming a closed economy, this class of works neglects the portion of technological knowledge affecting productivity that comes from abroad. From Grossman and Helpman (1991) onwards, numerous open-economy models have been developed to trace the benefits that technological laggards reap by interacting with frontier countries, namely international technology spillovers. Among others, Caselli and Wilson (2004) shape cross-country productivity differences as dependent on R\&D embodied in equipment imports. A fully endogenous growth model with trade of capital goods (even though without R\&D) can be found in Eaton and Kortum (2001), whilst one based on learning-by-doing is proposed by Felbermayr (2007). Following this second strand of theoretical literature, it is by now a standard practice taking account of foreign research, along with domestic $R \& D$, in assessing the contribution of knowledge spillovers to productivity growth.

\subsection{Empirical evidence}

Productivity effects of IT. Most studies show that labor productivity growth has increasingly been driven by the direct effects of information technology, i.e. IT capital deepening and TFP growth in IT-producing industries (Jorgenson, 2005). ${ }^{1}$ By contrast, economy-wide spillovers of these new technologies are still poorly investigated, albeit they are considered a distinctive property of digital goods. Such indirect effects of IT typically take the form of network externalities and of knowledge spillovers associated with a faster circulation of ideas or a better information management; some corroborative evidence can be found in Fuss and Wavermann (2005) and Becchetti and Adriani (2005), respectively.

More generally, IT is regarded as a general purpose technology. Its adoption entails a period of experimentation at a firm level, during which both the business organization and the endowment of human capital need to be changed. The benefits of the adjustment finalised by first-users also accrue to imitators and, at an aggregate level, the related gains show up only in the long-run (delay hypothesis). Such a hypothesis is often advanced to explain why TFP growth is not statistically associated with the contemporaneous level of IT investment, while it occurs with its lagged values (see Stiroh, 2002 and Basu et al., 2004).

Productivity effects of R\&D. Since Griliches (1979), technological knowledge intended either as output of innovation activity or as input in production of new knowledge has been a central topic in productivity literature. Though, at an economy-wide level, it is only with Coe and Helpman (1995, henceforth CH) onwards that an increasing attention has been paid to international technology

\footnotetext{
${ }^{1}$ See Timmer and van Ark (2005) for a study focussed on the EU-US productivity gap and the role played by information technology.
} 
spillovers. ${ }^{2}$ Under the assumption that knowledge is embodied in intermediate goods imports, $\mathrm{CH}$ show that large benefits are associated to foreign R\&D (direction effect), and that they are proportional to a nation's trade openness (intensity effect). According to Keller (1998), however, this type of evidence does not corroborate the hypothesis that knowledge flows across countries through trade, since identical results arise whatever type of weights is adopted, even randomly generated. On the other hand, Lichtenberg and van Pottelsberghe (1998) show that better outcomes on trade-related spillovers are yielded by correcting the aggregation bias of the CH's weighting scheme.

Nowadays, there is large agreement that international spillovers substantially contribute to productivity growth, even more than domestic innovation. This argument has been confirmed by recent works using more sophisticated, trade-related weights (Lumenga-Neso et al., 2005), different measures of knowledge capital (Bottazzi and Peri, 2007; Madsen, 2007, and 2008), or alternative mechanism of knowledge propagation (Lee, 2006 and Mendi, 2007). It should be however emphasized that the differential impact between foreign and domestic R\&D might be reducing over time (Guellec and van Pottelsberghe, 2004) and such other factors as human capital and institutional characteristics may be influential for productivity growth (see Engelbrecht, 1997, Frantzen, 2000 and Coe et al., 2008). ${ }^{3}$

Interaction between IT and R\&D. Advances in information technology are claimed to shift the innovation possibility frontier of the economy, rather than directly shifting the production frontier (Bresnahan, 2001). The uptake of IT stimulates co-invention in users; this widens the potential for further applications, so to continually fuel the demand for IT capital. Because of such a dynamic feedback loop, IT producers are subject to increasing returns and, finally, information technology has permanent effects on economic growth.

Although the process of co-invention between IT and R\&D has long been recognized (Allen, 1986), econometric evidence on their complementary effects is scarce. Based on French micro data up to 1994, Greenan et al. (2001) find that computing equipment and research inputs are jointly significant within the

\footnotetext{
${ }^{2} \mathrm{~A}$ richer survey is provided in the working paper version of the article; see however Keller (2004) for an extended discussion on international technology spillovers.

${ }^{3}$ Aggregate evidence has recently been enriched by most industry-level studies, where intermediate transactions from input-output tables are used to gauge within-country spillovers (Keller, 2002a). Among others, this approach has been adopted by Acharya and Keller (2007) to assess the extent to which R\&D of each single frontier country affects the performance of technological laggards. The most generalized procedure has been implemented by Brandt (2007) that estimates a dual cost function admitting both cross-country and cross-industry heterogeneity in slope parameters. In alternative to intermediate transactions, Frantzen (2002) employs a patent-based indicator of technological proximity among industries, while Keller (2002b) also considers the geographical distance.
} 
cross-section dimension, but not along the time-series one. A consistent (crosssectional) result is found by Matteucci and Sterlacchini (2004) by studying a large sample of Italian firms during the golden years of the 'Information age' (19982000). At an economy-wide level, on the one hand, Madden and Savage (2000) and Lee (2008) detect that IT commodities imports are particularly conducive of knowledge spillovers; on the other hand, Lee (2005) and Zhu and Jeon (2007) show that international spillovers have been enhanced by the development of telecom infrastructures, especially after the advent of the Internet.

\section{Empirical setting}

\subsection{Analytical framework}

In line with the theoretical background, we start by considering the following closed-economy specification (model 1):

$$
\ln T F P_{i t}=\alpha_{0 i}+\alpha_{1} \ln I T_{i t}+\alpha_{2} \ln D R D_{i t}+\alpha_{3} C_{i t}+\epsilon_{i t},
$$

where $\mathrm{TFP}_{i t}$ is the index of total factor productivity, IT is the stock of information and communication technology capital, $\mathrm{DRD}_{i t}$ is the cumulative (domestic) expenditure in research and development. $\mathrm{C}_{i t}$ instead comprises a set of common time dummies and some control variables (expressed in logs) that will be introduced below. $\alpha_{0 i}$ are country fixed-effects, $\epsilon_{i t}$ the usual stationary errors. $i$ denotes countries $(i=1, \ldots, 15)$, and $t$ time periods $(t=1980, \ldots, 2003)$.

The slope parameters to be estimated represent the return excess of technicallyadvanced assets, i.e. the extent to which their social return exceeds the (private) remuneration to which they are paid for. Indeed, the direct contribution of each factor to economic growth is already incorporated into GDP volume: IT capital as separate input, while $R \& D$ expenses being included into current costs for research personnel and other non-capital materials, as well as into research capital expenditure (OECD, 2002b, p. 108). ${ }^{4}$ This means that the lack of a positive and significant coefficient should be interpreted as an indication that no extraordinary premium is associated with investment in IT or R\&D compared to traditional inputs.

In model 2, we examine the importance of productivity spillovers coming from the R\&D base of the IT-producing sector relatively to those of non-IT firms $\left(\mathrm{DRD}^{\lambda}, \lambda=I, N I\right)$. The specification to be estimated is thus shaped:

$$
\ln T F P_{i t}=\alpha_{0 i}+\alpha_{1} \ln I T_{i t}+\alpha_{2} \ln D R D_{i t}^{I}+\alpha_{3} \ln D R D_{i t}^{N I}+\alpha_{4} C_{i t}+\epsilon_{i t} .
$$

\footnotetext{
${ }^{4}$ See Guellec and van Pottelsberghe (2004) for an in-depth discussion on the so-called 'double counting' of R\&D.
} 
$\mathrm{DRD}^{I}$ is the R\&D stock of (domestic) IT firms, while DRD ${ }^{N I}$ the one developed by the (non-IT) remaining part of the market economy. Model 2 is aimed at excluding that the TFP-enhancing effect of the IT-related knowledge is taken up by the coefficient of IT assets as it may occur by adopting an aggregate measure of knowledge capital (see equation 1).

In model 3, we assess the relevance of imported technology spillovers by adding to the previous specification the R\&D stock developed abroad by both IT and non-IT sectors (FRD ${ }^{I}$ and $\left.\mathrm{FRD}^{N I}\right)$ :

$$
\begin{gathered}
\ln T F P_{i t}=\alpha_{0 i}+\alpha_{1} \ln I T_{i t}+\alpha_{2} \ln D R D_{i t}^{I}+\alpha_{3} \ln D R D_{i t}^{N I}+ \\
\alpha_{4} \ln F R D_{i t}^{I}+\alpha_{5} \ln F R D_{i t}^{N I}+\alpha_{6} C_{i t}+\epsilon_{i t} .
\end{gathered}
$$

Equation 3 is helpful to definitively confute the embodiment hypothesis for IT capital, i.e. that the significance of this factor does ultimately depend on the base of (both internal and foreign) R\&D it incorporates.

As a final step (model 4), the complementarity between technically-advanced assets is investigated by means of the two following specifications:

$$
\begin{gathered}
\ln T F P_{i t}=\alpha_{0 i}+\alpha_{1} \ln I T_{i t}+\alpha_{2} \ln D R D_{i t}+\alpha_{3} \ln F R D_{i t}+ \\
\alpha_{4} m_{I} \ln D R D+\alpha_{5} m_{I} \ln F R D+\alpha_{6} C_{i t}+\epsilon_{i t}
\end{gathered}
$$

and

$\ln T F P_{i t}=\alpha_{0 i}+\alpha_{1} \ln I T_{i t}+\alpha_{2} \ln D R D_{i t}+\alpha_{3} \ln F R D_{i t}+\alpha_{4} m_{R} \ln I T+\alpha_{5} C_{i t}+\epsilon_{i t}$,

where $m_{I}$ and $m_{R}$ respectively denote the share of IT and R\&D investment on GDP (in current prices). The goal of equation (4a) is of verifying whether ITintensive countries gain larger benefits from R\&D capital as a consequence of a faster circulation of ideas or a higher research productivity associated with the usage of the new types of IT equipment. On the other hand, equation (4b) checks whether a solid knowledge endowment is a prerequisite to more intensively exploit the growth potential of IT capital. Two points are noteworthy with regard to model (4). Firstly, consistently with the previous equations, DRD, FRD and $m_{R}$ will be disentangled between IT and non-IT producing industries (i.e. $\mathrm{DRD}^{\lambda}, \mathrm{FRD}^{\lambda}, \mathrm{m}_{R}^{\lambda}$, $\lambda=I, N I)$. Secondly, by interacting capital stocks with the shares of hightech investment on GDP, we admit heterogeneity in complementarity effects; the corresponding elasticities are given by $\epsilon_{I}^{D R D}=\alpha_{4} * m_{I}$ and $\epsilon_{I}^{F R D}=\alpha_{5} * m_{I}$ for equation (4a), and by $\epsilon_{R}^{I}=\alpha_{4} * m_{R}$ for (4b). 


\subsection{Building foreign knowledge}

The external stock of technological knowledge is computed using the weighting method devised by Lichtenberg and van Pottelsberghe (1998, hereinafter LP). Unlike the CH's scheme, this procedure is invariant to the level of data aggregation, as the size of foreign knowledge does not rise by merging two (or more) exporting countries. Foreign knowledge owned by each type of firms is computed by weighting $R \& D$ capital with the current prices ratio between the exports towards the recipient countries and its value-added $\left(\mathrm{FRD}^{\lambda}\right.$ and $\left.\lambda=I, N I\right)$ :

$$
F R D_{i t}^{\lambda, F}=\sum_{j=1}^{15} \frac{M_{j i t}^{\lambda, F}}{Y_{j t}^{\lambda, F}} D R D_{j t}^{\lambda}, \quad i \neq j \quad \lambda=I, N I, \quad t=1980, \ldots, 2003 .
$$

$\mathrm{DRD}_{j t}^{\lambda}$ is the knowledge stock of sector $\lambda$ at time $t$ in country $j, \mathbf{M}_{j i t}^{\lambda, F}$ the export flow of industry $\lambda$ in country $j$ towards the recipient country $i, \mathrm{Y}_{j t}^{\lambda, F}$ is the valueadded of the exporting industry.

Since imports exhibit large variations over time, and these are proportional to the level of disaggregation of commodity flows' data, two additional types of weights are used to validate the results' robustness. By construction, they are less sensitive to temporary changes in trade figures and, consequently, should more accurately reflect the permanent effects of external knowledge on TFP. Firstly, we build a smoothed LP indicator using a 3-year moving average of the flows of exports and value-added $\left(\bar{M}_{j i t}^{\lambda, F}\right.$ and $\left.\bar{Y}_{j t}^{\lambda, F}\right)$ :

$$
F R D^{\lambda, \bar{F}}=\sum_{j=1}^{15} \frac{\bar{M}_{j i t}^{\lambda, F}}{\bar{Y}_{j t}^{\lambda, F}} D R D_{j t}^{\lambda}, \quad i \neq j \quad \lambda=I, N I, \quad t=1980, \ldots, 2003 .
$$

Secondly, we construct the stocks-based version of the LP's weights proposed by Madsen (2007); it rests on the current price ratio between the cumulative value of exports and value-added $\left(M_{j i t}^{\lambda, S}\right.$ and $\left.Y_{j t}^{\lambda, S}\right)$ :

$$
F R D_{i t}^{\lambda, S}=\sum_{j=1}^{15} \frac{M_{j i t}^{\lambda, S}}{Y_{j t}^{\lambda, S}} D R D_{j t}^{\lambda}, \quad i \neq j \quad \lambda=I, N I, \quad t=1980, \ldots, 2003,
$$

where

$$
M_{j i t}^{\lambda, S}=M_{j i t}^{\lambda, F}+(1-\delta) M_{j i t-1}^{\lambda, S} \quad Y_{j t}^{\lambda, S}=Y_{j t}^{\lambda, F}+(1-\delta) Y_{j t-1}^{\lambda, S},
$$

and $\delta$ is the depreciation rate utilized in building knowledge capital $(\delta=0.15)$. The stocks-based measure of foreign $R \& D$ collapses into the original one proposed by Lichtenberg and van Pottelsberghe (1998) when there is full depreciation for imported knowledge $(\delta=1)$. 


\subsection{Econometric issues}

The elasticity of TFP to technically-advanced capital is likely to be higher when estimated at higher levels of data aggregation, as allowing to better capture their social returns (Griliches, 1992). A long-run (dynamic) perspective of analysis is typically adopted in the related literature to overcome the (static) compensation between the performance of innovative and less innovative firms (or industries), as making aggregate spillovers hard to show up in a short-term horizon. Cointegration techniques are particularly attractive in this respect since they are robust to such issues usually plaguing estimates as endogeneity, omitted variables, and measurement errors.

In this paper we use the panel dynamic OLS estimator developed by Mark and Sul (2003). It represents the panel extension of the single-equation procedure devised by Saikkonen (1991), whose properties have earlier been studied by Kao and Chiang (2000) under more restrictive conditions. Panel DOLS assumes homogenous coefficients across equations (or countries) and estimates the cointegration relation by introducing into each country equation lags and leads of the first-differenced regressors with the view to eliminating the endogeneity bias. Albeit based on the hypothesis of errors' independence, panel dynamic OLS performs well even for low degree of cross-section dependence; this effect can be easily allowed for by working with cross-sectionally demeaned variables, that is equivalent to using common time dummies.

The dynamic properties of the variables are studied through the panel unit roots test developed by Pesaran (2007), CIPS, and the cointegration tests devised by Westerlund (2005), $\mathrm{VR}_{G}$ and $\mathrm{VR}_{P}$. The CIPS statistic tests the nonstationarity of the series, consisting in the mean of the t-ratio statistics yielded by cross-sectionally augmented Dickey-Fuller regressions (CADF). These are standard DF specifications enriched with the lagged value of cross-section mean and its contemporaneous first difference; such variables are effective for removing the effect of cross dependence, which is assumed to be shaped as a one-factor model. ${ }^{5}$

The variance ratio statistics developed by Westerlund (2005) consist in stationarity tests on the residuals of the potentially cointegrated relation and, accordingly, their null hypothesis is of no cointegration. These tests are defined as the sum over both the time- and cross-section dimension of the product between the square of the residuals' partial sum and the total sum of the residuals' square. The panel mean variance statistics, $\mathrm{VR}_{P}$, is built by summing the separate terms over the cross sections prior to multiplying them together, the group mean variance statistics, $\mathrm{VR}_{G}$, by first multiplying the various terms and then summing over the cross-sectional dimension. The alternative hypothesis of $\mathrm{VR}_{P}$ is that the panel is

\footnotetext{
${ }^{5}$ Serial correlation is controlled for by including lagged first-differences of the dependent variable and their cross-section mean.
} 
cointegrated as a whole, for $\mathrm{VR}_{G}$ that there is a positive fraction of cointegrated individuals. By construction, $\mathrm{VR}_{G}$ accommodates a larger degree of heterogeneity, lowering the risk of accepting the null hypothesis of no cointegration in small samples because of a few individuals. By contrast, the rejection of the null hypothesis by the $\mathrm{VR}_{P}$ test provides strong evidence in favor of cointegration. ${ }^{6}$

\section{Data description}

\subsection{Data sources and methodology}

This study examines a sample of OECD countries composed by the United States and the former EU-15 members (excluding Luxembourg) over the period 19802003. Aggregate total factor productivity (TFP) is calculated as residual growth of GDP over the income share-weighted rise of factor inputs, hypothesizing perfectly competitive markets and constant returns to scale. TFP is indexed to 100 in a benchmark year (2000).

National Accounts series are taken from the GGDC Total Economy Growth Accounting database. ${ }^{7}$ It collects data on GDP, hours worked and various types of capital assets (IT and non-IT) from national statistical offices. IT capital includes office machinery and information equipment, communication equipment and software. On the other hand, non-IT capital comprises non-residential buildings, transport equipment and non-IT equipment. National Accounts series are constructed using the Tornqvist index formula; it aggregates sub-categories with continuously updated shares, turning out to be the exact formula (superlative index) when the underlying (flexible) production function is a translog. These properties make the Tornqvist index more appropriate for productivity estimates than base-year (Laspeyres) indexes applied to a Cobb-Douglas type of production function (Griffith et al., 2004).

The stock of knowledge capital is built from $R \& D$ expenditure series reported in the OECD Main Science and Technology Indicators and ANBERD database. ${ }^{8}$ Below, we carry out separate regressions using either gross expenditure in research and development (GERD) or business enterprise R\&D (BERD) as measure of knowledge capital. Along with BERD, the former includes the expenses

\footnotetext{
${ }^{6}$ Although both VR statistics hinge on the assumption of errors' independence, they perform optimally even in presence of a low degree of cross-section dependence (i.e. the case with common time dummies), and moderately well for higher levels of correlation. In both cases, their smallsample distortion is inferior to that emerging with other popular panel cointegration tests; see Westerlund (2005).

${ }^{7}$ Groningen Growth and Development Centre. Details can be found in Timmer et al. (2003).

${ }^{8} \operatorname{OECD}(2007$, and 2002a).
} 
of public research labs, the higher education sector and other non-profits institutions; for simplicity, the difference between GERD and BERD is labelled as public research capital (PRD). The broadest indicator of knowledge capital (GERD) is utilized as being more consistent with data on IT assets, that refer to the total economy. Though, the focus will be later restricted to business sector; indeed, the main goal of this study is of quantifying the productivity spillovers of IT and R\&D capital, and it is well-known that the advances in the field of digital technologies are strictly related to the initiative of privately-owned firms. In this respect, business R\&D will also be disentangled into the one performed by the IT-producing industry and that of the remaining market industries, defined as non-IT producers. IT (manufacturing) industry includes office machinery and communication equipment (categories 30 and 32, ISIC Rev. 3). On the other hand, the stock of foreign $\mathrm{R} \& \mathrm{D}$ is constructed using data on bilateral trade by commodity and industry, respectively taken from the OECD International Trade by Commodities Statistics and STAN Bilateral Trade database. ${ }^{9}$

In robustness checks, as control variables we employ the average number of schooling years and an alternative indicator of knowledge capital based on patent data. The former is extracted from the data set recently developed by Cohen and Soto (2007); for the latter, we rest on patent applications at the European Patent Office and patent grants at the US Patent and Trademark Office, collected in OECD Main Science and Technology Indicators and in NBER Patent Data files (Hall et al., 2001). Further details on the sources and the methodology followed in data construction (permanent inventory method, PPP conversion, etc.) are provided in the Appendix.

\subsection{Descriptive analysis}

Table 1 reports the average annual percentages of change of the variables that will be employed in the econometric analysis. TFP grew by a $1.3 \%$ per year in our sample, showing however a remarkable variation across countries. The accumulation of IT capital has been relatively more homogenous, amounting to an annual 14\%; this reflects the harmonization in investment deflators implemented at GGDC. Indeed, in order to consistently treat the quality growth of high-tech goods over time, IT investment has been deflated by applying the hedonic price indexes developed by the Bureau of Economic Analysis for the US, corrected for cross-country differences in general inflation (Schreyer, 2002).

Looking at knowledge capital, it emerges that the broadest measure of R\&D expanded at a rate of $5.4 \%$ per year, while that of business sector at a $6.6 \%$. They both grew faster in those countries that were less involved in research activity at

\footnotetext{
${ }^{9}$ OECD (2002c, 2006a and 2006c).
} 
Table 1: Growth of TFP and technically-advanced capital, 1980-2003 (average annual percentages of change)

\begin{tabular}{lcccccccc}
\hline \hline & TFP & IT & $\begin{array}{c}\text { DRD- } \\
\text { GERD }\end{array}$ & $\begin{array}{c}\text { DRD- } \\
\text { BERD }\end{array}$ & DRD $^{I}$ & DRD $^{N I}$ & FRD $^{I}$ & FRD $^{N I}$ \\
Austria & 1.1 & 12.7 & 5.4 & 6.4 & 6.6 & 6.9 & 11.9 & 4.2 \\
Belgium & 1.4 & 15.6 & 3.0 & 3.5 & 5.1 & 3.8 & 13.4 & 3.1 \\
Denmark & 0.8 & 15.4 & 6.3 & 8.0 & 10.3 & 8.4 & 13.6 & 3.1 \\
Finland & 2.2 & 13.9 & 8.7 & 10.8 & 21.7 & 7.1 & 16.1 & 4.7 \\
France & 1.2 & 13.9 & 4.3 & 5.6 & 16.3 & 4.3 & 11.0 & 3.6 \\
Germany & 1.9 & 11.9 & 2.5 & 2.7 & 5.2 & 2.6 & 14.4 & 3.7 \\
Greece & 0.6 & 13.5 & 7.5 & 9.6 & 20.3 & 8.8 & 15.5 & 3.7 \\
Ireland & 2.7 & 17.2 & 8.1 & 10.9 & 14.9 & 10.3 & 14.8 & 4.5 \\
Italy & 0.7 & 12.4 & 3.2 & 2.8 & 4.5 & 2.9 & 12.1 & 3.7 \\
Netherlands & 0.9 & 15.6 & 2.8 & 3.4 & 8.6 & 2.6 & 11.2 & 2.7 \\
Portugal & 1.2 & 13.0 & 8.1 & 8.7 & 8.4 & 9.5 & 15.6 & 5.5 \\
Spain & 0.6 & 15.0 & 7.4 & 8.5 & 9.1 & 8.9 & 15.8 & 8.3 \\
Sweden & 1.2 & 14.5 & 6.6 & 8.2 & 21.0 & 5.3 & 11.7 & 3.2 \\
United Kingdom & 1.3 & 17.4 & 1.2 & 1.7 & -0.6 & 3.1 & 16.3 & 5.0 \\
United States & 1.1 & 14.1 & 6.5 & 7.9 & 23.1 & 4.3 & 13.0 & 6.4 \\
& & & & & & & & \\
TOTAL & 1.3 & 14.4 & 5.4 & 6.6 & 11.6 & 5.9 & 13.8 & 4.4 \\
\hline \hline
\end{tabular}

Notes. TFP: total factor productivity; IT: IT capital stock; DRD: domestic R\&D stock; DRD ${ }^{I}$ : domestic R\&D of IT industry; DRD ${ }^{N I}$ : domestic R\&D of non-IT industry; FRD $^{I}$ : foreign R\&D of IT industry; FRD ${ }^{N I}$ : foreign R\&D of non-IT industry. Foreign R\&D is constructed using standard LP weights.

the beginning of the period. Among the larger countries, the BERD stock expanded slowly except than in the US; this country has in fact reinforced its leadership in R\&D-based innovation, especially from the mid-1990s when it outpaced the knowledge accumulation of the other big economies.

A more detailed outline on knowledge generation can be traced by comparing the performance of IT firms with the one of the remaining economy. On average, R\&D capital rose at a double digit rate in the former industry, $11.6 \%$ against $5.9 \%$ of the non-IT sector. ${ }^{10}$ The knowledge stock did expand more rapidly in the latter (non-IT) part of the market economy only in the UK and Portugal.

The last two columns of Table 1 report the growth rate of foreign $R \& D$ distinguished by industry types (based on standard LP weights). As a mirror of the increase in both international trade and IT-related research, FRD $^{I}$ grew faster than domestic R\&D (on average, 13.8 vs $11.6 \%$ ); by contrast, the expansion of FRD ${ }^{N I}$ has been rather flat almost everywhere, increasing by $4.4 \%$ annually.

\footnotetext{
${ }^{10}$ At an industry-level, R\&D expenditure has been deflated through the price index of valueadded. These series are taken from EU KLEMS database where no harmonization is done for the IT sector, implying that only a minority of countries employ price indexes adjusted to control for quality growth of IT output (Timmer et al., 2007, p. 38). These methodological issues will further be discussed below, and shown to leave unaffected our key results.
} 


\section{Econometric results}

Closed-economy framework (Model 1). This section starts by showing the estimation of equation (1). Along with the estimated elasticities, Table 2 reports the value of the panel unit roots and cointegration tests. The CIPS statistic checks that all the panel units are non-stationary, diverging towards a negative infinite under the alternative hypothesis; $\mathrm{VR}_{G}$ and $\mathrm{VR}_{P}$ assume the null hypothesis of no cointegration, and are distributed as a negative, one-sided standard normal. ${ }^{11}$

Initially, productivity is regressed on IT capital and the total-economy measure of R\&D (GERD, column i); ${ }^{12}$ factor elasticities respectively amount to 0.063 and 0.107 , falling in the range of values reported in earlier works. Regression (ii) shows however that business R\&D is the only source of spillovers (0.118), being public research insignificant. The finding for PRD might depend on a compensation between the effects of the higher education sector and that of government agencies; alternatively, PRD might indirectly affect TFP by stimulating private research (Park, 1995, p. 581). When PRD is left out (column iii), business R\&D soars up to 0.128 , while IT capital falls to 0.047 . Both types of technicallyadvanced capital are thus characterised by excess of returns. The elasticity of business $R \& D$ is likely to gauge the social returns of knowledge-generating processes, i.e. inter-firm and inter-industry (non-pecuniary) externalities; the coefficient of IT capital most probably captures both networking effects and specific knowledge spillovers.

As discussed above, both R\&D and IT capital are correlated with human capital, implying that the elasticities so far estimated may be upward biased by the omission of such a factor. To control for this issue, a measure of human capital is added to equation (1). This variable has been constructed from data on educational levels using the Mincherian approach, $H_{t}=e^{\phi * y s_{t}}$, where $y s_{t}$ are the average years of schooling for people aged 25 and over, and $\phi$ a positive parameter assumed constant across countries and over time (Cohen and Soto, 2007). This regressor however turns out to be insignificant and, accordingly, the coefficients of IT and business R\&D capital remain unchanged (col. iv).

In column (v), hours worked are used as explanatory variable to exclude any possible distortion related to the presence of increasing returns to scale. TFP has been indeed computed assuming constant returns, leading the Solow's residual to overstate the true level of technical progress when this assumption is violated. The risk is that factor elasticities are oversized due to presence of increasing returns,

\footnotetext{
${ }^{11}$ Because of the different treatment of cross-section dependence, the CIPS test is carried out on original series, while $\mathrm{VR}_{G}$ and $\mathrm{VR}_{P}$ on cross-sectionally demeaned variables (see section 3.3).

${ }^{12}$ In the regression analysis, one-year lags and leads of the regressors' first-differences are inserted into the specifications to be estimated. The GAUSS codes used are taken from the Donggyu Sul's homepage (http://homes.eco.auckland.ac.nz/dsul013/).
} 


\begin{tabular}{|c|c|c|c|c|c|c|c|c|}
\hline \multirow[t]{2}{*}{ Table } & \multicolumn{2}{|c|}{ Closed-economy } & \multicolumn{2}{|c|}{ estimates } & \multicolumn{2}{|c|}{ productivity } & \multicolumn{2}{|c|}{ spillovers } \\
\hline & (i) & (ii) & (iii) & (iv) & (v) & (vi) & (vii) & $\overline{C I P S}$ \\
\hline $\ln T F P$ (dep.) & & & & & & & & -0.27 \\
\hline $\ln \mathrm{IT}$ & $0.063^{* *}$ & $0.060^{* *}$ & $0.047^{* *}$ & $0.049^{* *}$ & $0.069^{* *}$ & $0.051^{* *}$ & $0.050^{* *}$ & -0.91 \\
\hline & $(0.012)$ & $(0.011)$ & $(0.014)$ & $(0.020)$ & $(0.012)$ & $(0.008)$ & $(0.012)$ & \\
\hline In DRD-GERD & $\begin{array}{l}0.107^{* *} \\
(0.034)\end{array}$ & & & & & & & -1.04 \\
\hline In DRD-PRD & & $\begin{array}{l}-0.005 \\
(0.041)\end{array}$ & & & & & & 0.22 \\
\hline In DRD-BERD & & $0.118^{* *}$ & $0.128^{* *}$ & $0.125^{* *}$ & $0.088^{* *}$ & $0.161^{* *}$ & $0.101^{* *}$ & 0.01 \\
\hline & & $(0.048)$ & $(0.041)$ & $(0.049)$ & $(0.020)$ & $(0.030)$ & $(0.035)$ & \\
\hline ln Human capital & & & & $\begin{array}{l}-0.010 \\
(0.044)\end{array}$ & & & & -0.66 \\
\hline ln Hours worked & & & & & $\begin{array}{l}-0.224^{* *} \\
(0.097)\end{array}$ & & & -1.42 \\
\hline In Patents Ppo $_{\text {P }}$ & & & & & & $\begin{array}{l}-0.019 \\
(0.025)\end{array}$ & & $-2.70^{* *}$ \\
\hline ln Patents uspto $_{\text {I }}$ & & & & & & & $\begin{array}{l}0.021 \\
(0.036)\end{array}$ & -2.11 \\
\hline$V R_{G}$ & $-2.24^{* *}$ & $-2.40^{* *}$ & $-2.05^{* *}$ & $-1.72^{* *}$ & -1.23 & $-2.46^{* *}$ & $-2.43^{* *}$ & \\
\hline$V R_{P}$ & $-2.07^{* *}$ & $-1.55^{*}$ & $-1.88^{* *}$ & $-1.32^{*}$ & -0.92 & $-1.52 *$ & $-1.60^{*}$ & \\
\hline
\end{tabular}

Notes. Any specification includes country fixed-effects and common time dummies. Standard errors based on Andrews and Monahan's pre-whitening method in parentheses. TFP: total factor productivity; IT: IT capital; DRD: domestic R\&D stock; Patents epo: stock of patent applications at EPO; Patents uspto: stock of patent grants at USPTO. CIPS checks that all series are non-stationary. $\mathrm{VR}_{P}$ checks that there is no cointegration in all panel individuals, while $\mathrm{VR}_{G}$ that it occurs for a positive fraction. Critical values (5 and 10\%): CIPS: -2.25 and $-2.14 . \mathrm{VR}_{G}-\mathrm{VR}_{P}:-1.64$ and -1.28 .

rather than capturing genuine technology spillovers. This possibility is however ruled out by the negative sign of labour elasticity (-0.224), indicating the presence of decreasing returns in our sample. Compared to the previous estimates, the coefficient of IT capital is somewhat higher (0.069), whilst that of R\&D lower (0.088).

As a further robustness check, equation (1) is estimated by introducing the stock of patented ideas. Notoriously, R\&D expenditure is only an input of the knowledge-generating process, being thus an imperfect measure of innovation stimulating economic growth; this mismeasurement may lead the coefficient of IT capital to be upward biased. In column (vi), we use the stock of patent applications at the European Patents Office. Probably, it is the most exhaustive output indicator of the inventive processes occurring in Europe. Though, only a fraction of applications is accepted at the end of examination (about 60\%), as most fail to meet the requisites to be granted; hence, the EPO indicator might not be a powerful control. Regression (vii) seeks to fill this lack by employing the stock of patent grants at the US Patent and Trademark Office. This measure understates the extent of the commercially-exploitable ideas developed in Europe; on the other hand, EU firms are likely to apply in the United States their breakthrough inventions, especially in the high-tech fields, because of the prominence of the US market. As 
shown by regressions (vi) and (vii), however, both measures of patented ideas are insignificant leaving almost unaffected the coefficient of IT capital. ${ }^{13}$

IT-related knowledge spillovers: closed-economy framework (Model 2). The focus is now shifted to the role of specialization in IT production in terms of contribution of knowledge spillovers to productivity growth. This step appears interesting for a twofold reason. Firstly, it enriches with econometric evidence the literature on the economy-wide impact of IT usage and production, which is mainly based on growth accounts. Secondly, the maximum emphasis is placed upon one of the sectors most innovation-intensive, and that is considered the engine of the emerging knowledge economy (Ulku, 2007).

For comparative aims, Table 3 displays in column (i) the key results found above. In column (ii), the productivity effects of business R\&D are separated into the spillovers related to the IT sector and those imputable to the rest of the market economy $(0.037$ and 0.120$)$. It should be first noted that the sum of these coefficients largely exceeds the elasticity found for total business R\&D (0.128). On the other hand, the coefficient of IT capital is remarkably lower, and now is significant only at a $10 \%$ level. This finding confirms that the impact of this factor is likely to be overstated when IT-related R\&D spillovers are not explicitly taken into consideration. Most importantly, regression (ii) highlights the influential role of the knowledge base of IT producers for the modern growth process; although this industry only accounts for between 1 and 3\% of business-sector employment (or value-added), it performs about $20 \%$ of private research, delivering large productivity gains to the overall economy.

Dealing with IT, intended either as investment goods or as industry output, a typical concern is the difficulty of correctly measuring its quality improvement over time. As discussed above, the real value of IT investment has been calculated by applying the harmonized indexes developed at GGDC on the basis of the US hedonic prices. On the other hand, R\&D expenditure has been converted into a constant-prices base through the industry deflators for value-added, taken from EU KLEMS dataset. For the IT sector, only a handful of countries employ hedonic methods to allow for the rising quality of output, while most still hinge on matching models; this artificially creates a disparity in the dynamics of research expenses. At the same time, for the majority of countries, there is an uneven treatment between the quality of IT assets and that $f$ the knowledge stock of IT producers, since the former is harmonised while the latter being not adjusted. It

\footnotetext{
${ }^{13}$ The tests reported at the margins of Table 2 provide sufficient guarantee of the existence of cointegration between productivity and technically-advanced assets. The variance ratio tests fail to reject the null hypothesis only in regression (iv); apart from this case, the fact that $\mathrm{VR}_{G}$ always indicates the presence of cointegration, while $\mathrm{VR}_{P}$ falling at the limit of significance, suggests that heterogeneity is confined to a few countries.
} 
Table 3. Closed-economy estimates of productivity spillovers: IT-related R\&D externalities

\begin{tabular}{lccccc|c}
\hline \hline & (i) & (ii) & (iii) $^{a}$ & (iv) & $(\mathrm{v})^{b}$ & $C I P S$ \\
$\ln$ TFP (dep.) & & & & & & -0.27 \\
$\ln$ IT & $0.047^{* *}$ & $0.021^{*}$ & $0.097^{* *}$ & $0.025^{* *}$ & $0.061^{* *}$ & -0.91 \\
& $(0.014)$ & $(0.012)$ & $(0.034)$ & $(0.008)$ & $(0.006)$ & \\
$\ln$ DRD-BERD & $0.128^{* *}$ & & & & & 0.01 \\
& $(0.041)$ & & & & & \\
$\ln$ DRD $^{I}$ & & $0.037^{* *}$ & $0.038^{*}$ & $0.020^{* *}$ & $0.025^{* *}$ & -0.37 \\
& & $(0.009)$ & $(0.023)$ & $(0.008)$ & $(0.010)$ & \\
$\ln$ DRD $^{N I}$ & & $0.120^{* *}$ & $0.156^{* *}$ & $0.101^{* *}$ & $0.118^{* *}$ & -1.35 \\
& & $(0.025)$ & $(0.031)$ & $(0.023)$ & $(0.014)$ & \\
$\ln$ Patents $_{\text {epo }}^{I}$ & & & & $0.025^{* *}$ & & -1.54 \\
& & & & $(0.011)$ & & \\
$\ln$ Patents $_{\text {uspto }}^{I}$ & & & & & -0.029 & -0.95 \\
& & & & & $(0.015)$ & \\
\hline$V R_{G}$ & $-2.05^{* *}$ & $-2.45^{* *}$ & $-2.53^{* *}$ & $-2.40^{* *}$ & $-2.56^{* *}$ & \\
$V R_{P}$ & $-1.88^{* *}$ & $-1.48^{*}$ & $-1.60^{*}$ & $-1.30^{*}$ & $-1.52^{*}$ & \\
\hline \hline
\end{tabular}

Notes. Any specification includes country fixed-effects and common time dummies. Standard errors based on Andrews and Monahan's pre-whitening method in parentheses. a) uses variables built on non-hedonic deflators. c) refers to the period 1980-2002. TFP: total factor productivity; IT: IT capital; DRD: domestic R\&D stock; $\mathrm{DRD}^{I}$ : domestic R\&D of IT industry; DRD ${ }^{N I}$ : domestic R\&D of non-IT industry; Patents ${ }_{e p o}^{I}$ :stock of IT patent applications at EPO; Patents ${ }_{e p o}$ : stock of IT patent grants at USPTO. CIPS checks the null hypothesis that all series are non-stationary. $\mathrm{VR}_{P}$ checks that there is no cointegration in all panel individuals, while $\mathrm{VR}_{G}$ that it occurs for a positive fraction. Critical values (5 and 10\%): CIPS : 2.25 and $-2.14 . \mathrm{VR}_{G}$ and VR $P:-1.64$ and -1.28 ***, individuals, while $\mathrm{R}_{G}$ that it occus
significant respectively at 5 and $10 \%$.

should be noted that, in the case of IT capital, measurement errors involve both the dependent and explanatory variables and, hence, the direction of estimation bias is not clear (Stiroh, 2002). In order to understand the relevance of such issues, model 2 is re-estimated using a measure of these variables based on quality-unadjusted deflators (col. iii). ${ }^{14}$ This tentative exercise yields a remarkable change only in the coefficient of IT capital, that now amounts to 0.097. For this factor, the conservative elasticity arising from the usage of price harmonisation may be due to the cross-sample propagation of the noise associated with the type of measurement, attenuating towards zero the elasticities of column (ii). ${ }^{15}$

The last two regressions of Table 3 assess the extent to which our previous findings are affected by the input-based nature of knowledge indicator. To exclude the possibility that the coefficient of IT assets does capture the unmeasured innovative output of IT producers, the stock of ideas patented by this type of firms is introduced into equation (2). It is nonetheless possible to see that the elasticity

\footnotetext{
${ }^{14}$ IT investment has been deflated through the price index for non-IT investment, R\&D expenditure of IT industry through the value-added deflator of the non-IT part of the market economy. TFP series have also been re-calculated considering the new (quality unadjusted) series of IT capital. For TFP, the value of CIPS is -0.02 , for IT capital -1.52 , and -0.73 for DRD ${ }^{I}$.

${ }^{15}$ This argument seems to be confirmed by the (unreported) results obtained by correcting only the explanatory variables of eq. (2); in this case, the coefficient of IT capital falls between the values of columns (ii) and (iii).
} 
of IT capital remains significant using both EPO and USPTO data, ${ }^{16}$ even showing a marked increase in the latter case. The significance of the control variable in column (iv) suggests that R\&D expenses may be only partly capturing knowledge spillovers related to IT productions.

IT-related knowledge spillovers: open-economy framework (Model 3). Now, imported R\&D spillovers are taken into account. The estimates of equation (3) are displayed in Table 4 where the key closed-economy results are reported in column (i) as reference. A measure of foreign R\&D stock based on the usual LP weights is employed in regressions (ii) through (iv). The two subsequent sections adopt instead the trade shares respectively constructed on the three-year moving average and the cumulative flows of exports and value-added. In any set of regressions, we first introduce the foreign stock of total business $R \& D$ to facilitate the comparison with the related literature. Then, we add to the basic specification the R\&D capital accumulated abroad by the two industry types. Finally, the last regression of each section restricts on correlates driving productivity.

Expectedly, introducing the business-sector stock of foreign knowledge lowers both elasticities of domestic R\&D capital (column ii); on the other hand, the coefficient of IT capital is larger and abundantly more significant than in column (i). Compared to existing works, foreign $\mathrm{R} \& \mathrm{D}$ spillovers are rather modest in size, and only weakly significant. ${ }^{17}$ As suggested by the subsequent estimation (col. iii), a possible explanation is the diverging impact exerted by foreign research of IT and non-IT producers. Regressions (iii) shows indeed that the trade-weighted value of R\&D accumulated abroad by the IT industry, $\mathrm{FRD}^{I}$, has a negative effect $(-0.078)$, whilst that of $\mathrm{FRD}^{N I}$ is positive $(0.148)$. The latter is responsible for the fall in the coefficient of $\mathrm{DRD}^{N I}(0.049)$; the former result might instead reflect the competition effect associated with the import penetration of IT commodities: the less a country produces information technology (and accordingly the more imports), the more the related benefits are eroded by competitors. This phenomenon has been investigated by Bitzer and Geishecker (2006) within a more general (nonIT) setup. ${ }^{18}$ As a final step, column (iv) reports the results for the parsimonious

\footnotetext{
${ }^{16}$ USPTO data are available up to 2002.

${ }^{17}$ A problem with $\mathrm{FRD}^{F}$ is that it is not non-stationary for all countries, as indicated by the CIPS test $\left(-2.15^{*}\right)$; this clearly depends on $\mathrm{FRD}^{N I, F}$ for which the null hypothesis of non-stationarity is rejected at the highest level of significance $\left(-2.60^{* *}\right)$. As shown below, a similar finding emerges when employing the trade shares based on the cumulative value of import propensity, but not when adopting the smoothed flows. Thereby, for regressions (v) through (vii) the necessary conditions for the validity of the cointegration tests are fully fulfilled.

${ }^{18}$ The non-positive impact of $\mathrm{FRD}^{I}$ may derive from the type of oligopolistic competition characterizing the IT industry, where the most innovative players take all the market once they develop a new frontier technology (competition for the market). See Shapiro and Varian (1999) and Shy (2001).
} 
version of model 3, based on those variables that below will be shown to be robust determinants of TFP.

Moving to the next sets of regressions, estimates are slightly different and point out that trade variability matters in our framework; both $\mathrm{DRD}^{N I}$ and $\mathrm{FRD}^{I}$ are indeed insignificant in the extended specification of the model (col. vi and ix). ${ }^{19}$ Controlling for this effect turns out to be important to assess the permanent effects of foreign research, especially the one related to IT production that, by the way, is confirmed not to enhance TFP. ${ }^{20}$ Note however that the elasticities of the restricted model are fully consistent among estimation groups (col. iv, vii and $\mathrm{x}$ ).

In the light of such results, the R\&D base of the IT industry and the totaleconomy endowment of IT assets emerge as the most important sources of the within-country spillovers. This appears a highly valuable finding as aggregate evidence on the IT-related R\&D externalities is still poor, while most previous works failed to detect productivity spillovers associated with IT investment (see, among others, Stiroh, 2002 and Inklaar et al., 2008). On the other hand, international trade is confirmed to be an effective conduit for knowledge created in less technically-advanced (non-IT) sectors, neutralizing the research effort of domestic firms. ${ }^{21}$ Therefore, maintaining a minimum level of specialization in IT productions seems essential to compete on the international market as, at best, knowledge underlying these activities is not easily transferable across countries. It also suggests that dynamic economies of scale might be the driving force behind the ongoing concentration of research activity within the IT sector, which is coupled with an increasing geographical fragmentation of production.

Complementarity between technically-advanced assets (Model 4). As a final step of the work, we investigate the interaction between IT and R\&D. The analysis is restricted to the positive determinants of TFP found above, and employs as measure of foreign $R \& D$ the one based on smoothed trade weights (col. i). Along with the estimated coefficients and the corresponding standard errors, Table 5 reports in squared brackets the elasticities implied by the interaction terms $\left(\epsilon_{j}=\alpha_{j} * m_{j}\right)$; these values are computed by applying to the estimated coefficients $\left(\alpha_{j}\right)$ the cross-country average share of IT or R\&D investment on GDP $\left(m_{j}, j=I, R\right.$; reported on the bottom of the table).

\footnotetext{
${ }^{19}$ The value of CIPS test for the measures of foreign knowledge employed in regressions (v)(vii) is of -0.81 for FRD, -0.82 for $\mathrm{FRD}^{I}$, and -0.95 for $\mathrm{FRD}^{N I}$, whilst the ones entering regressions (viii)-(x) is of -1.48 for FRD, -0.87 for $\mathrm{FRD}^{I},-3.06^{* *}$ for $\mathrm{FRD}^{N I}$.

${ }^{20}$ Unreported results show that such elasticities are robust to the inclusion of human capital and the stock of ideas patented by IT industry (both at EPO and at USPTO).

${ }^{21}$ In line with earlier studies, cross-country spillovers contribute to productivity growth more than internal factors; see in particular Lumenga-Neso et al. (2005), Lee (2006), Bottazzi and Peri (2007) and Madsen (2008).
} 


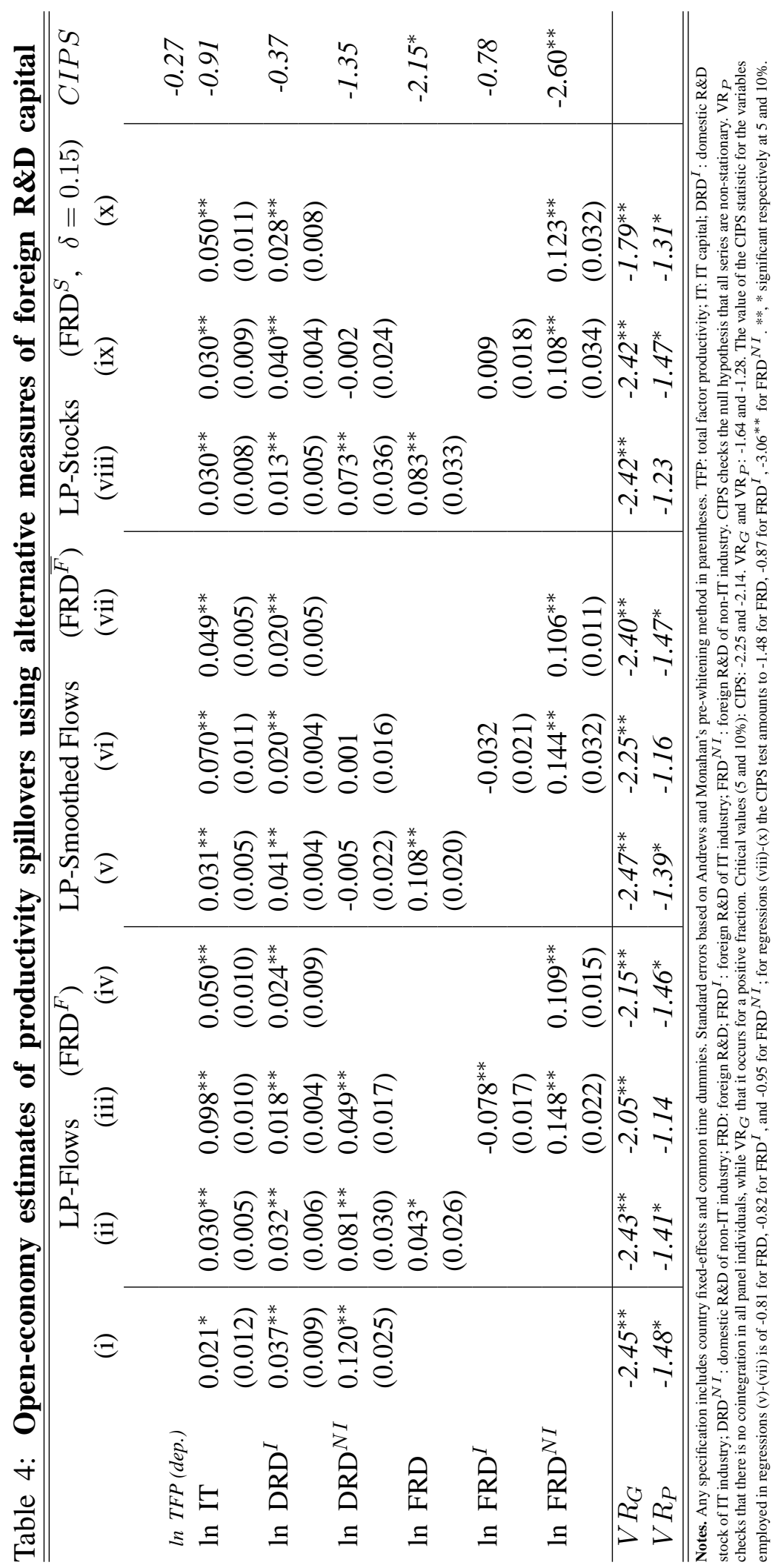


Equation (4a) is estimated through columns (ii) through (v) with the view to understanding whether $\mathrm{R} \& \mathrm{D}$ spillovers have been enhanced the rising adoption of IT goods. In most fields of science, research productivity has been spurred by the application of the new computer generations, as well as by a faster circulation of scientific knowledge enabled by the newly available, digital systems of communication. This kind of evidence however is far from showing up in aggregate estimates; indeed, the interaction coefficient turns out to be insignificant when we consider domestic R\&D capital $\left(m_{I} \ln \mathrm{DRD}\right)$, and even being negative if foreign knowledge is looked at $\left(m_{I} \ln \mathrm{FRD}\right.$; columns ii and iv). An industry-level inspection of the interaction relationship reveals that a negative effect is associated with non-IT related knowledge of both domestic and foreign firms, DRD ${ }^{N I}$ and FRD $^{N I}$ (-0.930 and -1.397); the magnitude of the underlying elasticities indicates that such effects are not economically negligible (-0.021 and -0.031). This finding can be interpreted in two alternative ways. On the one hand, IT investment might intrinsically be unfit to translate technologically backward knowledge into additional TFP gains; on the other hand, the complementarity effects between IT and R\&D may be lagging since digital assets do not still reach a critical threshold, or have been devoted to scarcely rewarding activities. By contrast, the positive sign of $m_{I} \ln \mathrm{FRD}^{I}$ (col. v) points out that a high share of IT investment is crucial for benefiting from international R\&D spillovers associated with IT production; note however that the elasticity implied by this coefficient is well below that found for $\mathrm{DRD}^{I}$ (0.016 against 0.029$)$, confirming that IT-related knowledge is scarcely transferable across countries.

Finally, the last two regressions of Table 5 assess whether a solid endowment of knowledge is helpful for raising the social returns of IT capital (equation (4b)). This may occur since research-intensive countries devote high-tech equipment to more productive tasks, they are better endowed with skilled workers or, simply, being characterized by a more favorable environment for innovation. Regressions (vi) and (vii) in fact indicate that (domestic) R\&D intensity is complementary to IT capital; nevertheless, for the R\&D effort of IT firms, it is difficult to distinguish this effect from the direct (not interacted) spillovers, as denoted by the insignificance or the negative sign of $\mathrm{DRD}^{I}$. In any case, looking at the elasticities reported in squared brackets, this type of complementarity appears economically marginal, in particular if compared to that found by estimating equation (4a) ${ }^{22}$

\footnotetext{
${ }^{22}$ As a whole, a larger cross-country heterogeneity emerges in estimating model 4 than the previous ones, as witnessed by the lower values taken by the cointegration tests.
} 


\begin{tabular}{ccccccccc|c} 
Table 5: & Estimates & of & interaction & between & IT & and & R\&D \\
\hline & & (i) & (ii) & (iii) & (iv) & (v) & (vi) & (vii) & $C I P S$
\end{tabular}

ln TFP (dep.)

$\begin{array}{cc}\text { (i) } & \text { (ii) } \\ & \\ 0.049^{* *} & 0.056^{* *} \\ (0.005) & (0.009) \\ 0.020^{* *} & 0.027^{* *} \\ (0.005) & (0.006) \\ 0.106^{* *} & 0.081^{* *} \\ (0.011) & (0.015)\end{array}$

$0.094^{* *}$

ln IT

$\ln \mathrm{DRD}^{I}$

$\begin{array}{lll}0.061^{* *} & 0.089^{* *} & 0.044^{* *}\end{array}$

$\begin{array}{llll}(0.015) & (0.010) & (0.011) & (0.004)\end{array}$

$0.061^{* *}$

$-0.27$

$\ln \mathrm{FRD}^{N I}$

$$
\text { (0.011) }
$$

(0.015)

$(0.009)$

$0.026^{* *}$

$0.029^{* *}$

0.002

(0.004)

(0.009)

(0.006)

(0.006)

(0.005)

$-0.016^{* *}$

(0.024)

(0.015)

(0.016)

$0.131^{* *}$

(0.006)

$0.132^{* *}$

(0.011)

Interactions with technically-advanced investment (as share of nominal GDP)

IT investment $_{I} \ln \mathrm{DRD}$
$m_{I} \ln \mathrm{DRD}^{I}$
$m_{I} \ln \mathrm{DRD}^{N I}$
$m_{I} \ln \mathrm{FRD}^{-}$
$m_{I} \ln \mathrm{FRD}^{I}$
$m_{I} \ln \mathrm{FRD}^{N I}$

$$
R=D R D^{\lambda}, F R D^{\lambda} \quad \lambda=I, N I
$$

$$
\begin{gathered}
0.391 \\
(0.409) \\
{[0.009]} \\
-0.930^{* *} \\
(0.418) \\
{[-0.021]}
\end{gathered}
$$

$-0.214^{*}$

$(0.115)$

[-0.005]

$$
\begin{gathered}
0.712^{* *} \\
(0.352) \\
{[0.016]} \\
-1.397^{* *} \\
(0.345) \\
{[-0.031]}
\end{gathered}
$$

R\&D investment $\left(m_{R}\right) \quad\left[\epsilon_{R}^{I}=\alpha * m_{R}^{\lambda}\right] \quad \lambda=I, N I$

$m_{R} \ln$ IT

$m_{R}^{I} \ln$ IT

$(0.142)$

[0.003]

$m_{R}^{N I} \ln$ IT

$0.348^{* *}$

$(0.160)$

[0.003]

Cross-country average share of technically-advanced investment on GDP

IT investment $\left(m_{I}\right)$ 0.022 0.022 0.022 0.022

$R \& D$ investment

Business sector $\left(m_{R}\right)$

IT industry $\left(m_{R}^{I}\right)$

non-IT industry $\left(m_{R}^{N I}\right)$

0.011

0.002

0.008

\begin{tabular}{lccccccc}
$V R_{G}$ & $-2.27^{* *}$ & $-1.87^{* *}$ & $-1.80^{* *}$ & $-1.82^{* *}$ & $-2.17^{* *}$ & $-2.43^{* *}$ & $-2.13^{* *}$ \\
$V R_{P}$ & $-1.47^{*}$ & -1.17 & -0.90 & -1.15 & -1.15 & $-1.39^{*}$ & -1.16 \\
\hline
\end{tabular}

Notes. Any specification includes country fixed-effects and common time dummies. Standard errors based on Andrews and Monahan's pre-whitening method in parentheses. Implied elasticities are reported in squared brackets $\left[\epsilon_{j}=\alpha_{j} * m_{j}\right.$ ]. TFP: total factor productivity; IT: IT capital; DRD ${ }^{I}$ : domestic R\&D stock of IT industry; $\mathrm{DRD}^{N I}$ : domestic R\&D of non-IT industry; FRD: foreign R\&D; $\mathrm{FRD}^{I}$ : foreign R\&D of IT industry; FRD ${ }^{N I}$ : foreign R\&D of non-IT industry CIPS checks the null hypothesis that all series are non-stationary. $\mathrm{VR}_{P}$ checks that there is no cointegration for all panel individuals, while $\mathrm{VR}_{G}$ that it occurs for a positive fraction. Critical values (5 and 10\%): CIPS: -2.25 and $-2.14 . \mathrm{VR}_{G}$ and $\mathrm{VR}_{P}:-1.64$ and -1.28 .**, * significant respectively at 5 and $10 \%$. 


\section{Concluding Remarks}

This paper has examined the role played by both IT and R\&D in the growth process of modern knowledge economies. According to our results, investing in IT assets is highly recommendable to stimulate economic growth, as delivering productivity gains distinct from $\mathrm{R} \& \mathrm{D}$, probably due to network externalities or specific knowledge spillovers. Though, this strategy appears only partly helpful for offsetting a country's low specialization in IT production. Indeed, in contrast to less technically-advanced industries for which trade is a robust enabler of crosscountry R\&D spillovers, the type of knowledge underlying the IT sector is less easily transferable abroad. It suggests that, in the current technological age, extraordinary efforts should be conducted by any modern economy to retain some competitive advantage in high-tech (IT) productions (even though limited to very small segments) in order to improve their long-run growth prospects.

\section{References}

ACHARYA, R. C. AND KelLeR, W. (2007). Technology Transfer Through Imports. CEPR Discussion Paper No. 6296.

ALlen, T. J. (1986). Organizational Structure, Information Technology and $R \& D$ Productivity. Paper presented at the Conference of the European Industrial Research Managers' Association, The Hague, Netherlands, June 5, 1985.

Basu, S., Fernald, J., Oulton, N. And SRinivasan, S. (2004). The Case of the Missing Productivity Growth: Or, Does Information Technology Explain why Productivity Accelerated in the United States but not in the United Kingdom? In NBER Macroeconomics Annual 2003 (edited by Gertler, M. And Rogoff, K.), pp. 9-63. The MIT Press, Cambridge, MA.

Becchetti, L. And Adriani, F. (2005). Does the Digital Divide Matter? The Role of Information and Communication Technology in Cross-Country Level and Growth Estimates. Economics of Innovation and New Technology, 14(6): 435-453.

BitZer, J. And Geishecker, I. (2006). What Drives Trade-related R\&D Spillovers? Decomposing Knowledge-Diffusing Trade Flows. Economics Letters, 93(1): 52-57.

BotTAzZI, L. AND PeRI, G. (2007). The International Dynamics of $R \& D$ and Innovation in the Short and Long Run. Economic Journal, 117(3): 486-511.

BRANDT, N. (2007). Mark-ups, Economies of Scale and the Role of Knowledge Spillovers in OECD Industries. European Economic Review, 51(7): 1708-1732.

Bresnahan, T. F. (2001). The Mechanisms of Information Technology's Contribution to Economic Growth. Presented at the Saint-Gobain Centre for Economic Research conference 'What Do We Know about the Sources of Technical Change?, Paris, 7-8 June 2001. 
CASElli, F. AND Wilson, D. J. (2004). Importing Technology. Journal of Monetary Economics, 51: $1-32$.

Coe, D. T. And Helpman, E. (1995). International $R \& D$ Spillovers. European Economic Review, 39(5): 859-887.

Coe, D. T., Helpman, E. And Hoffmaister, A. W. (2008). International R\&D Spillovers and Institutions. NBER Working Paper No. 14069.

Cohen, D. And Soto, M. (2007). Growth and Human Capital: Good Data, Good Results. Journal of Economic Growth, 12(1): 51-76.

Eaton, J. And Kortum, S. (2001). Trade in Capital Goods. European Economic Review, 45(7): 1195-1235.

Engelbrecht, H.-J. (1997). International R\&D Spillover, Human Capital and Productivity in OECD Economies: An Empirical Investigation. European Economic Review, 41(8): 14791488.

Felbermayr, G. J. (2007). Specialization on a Technologically Stagnant Sector Need not Be Bad for Growth. Oxford Economic Papers, 59(4): 682-701.

Frantzen, D. (2000). R\&D, Human Capital and International Technology Spillovers: A CrossCountry Analysis. Scandinavian Journal of Economics, 102(1): 57-75.

- (2002). Intersectoral and International R\&D Knowledge Spillovers and Total Factor Productivity. Scottish Journal of Political Economy, 49(3): 280-303.

Fuss, M. And Wavermann, L. (2005). The Networked Computers: the Contribution of Computing \& Telecommunications to Economic Growth Productivity OR Why is there no New Economy in Old Europe. a Production Function Approach. London Business School, Digital Transformations Working Paper No. 1.

Greenan, N., Mairesse, J. ANd Topiol-Bensald, A. (2001). Information Technology and Research and Development Impacts on Productivity and Skills: Looking for Correlations on French Level Data. NBER Working Paper No. 8075.

Griffith, R., Redding, S. And van Reenen, J. (2004). Mapping the Two Faces of R\&D: Productivity Growth in a Panel of OECD Industries. Review of Economics and Statistics, 86(4): 883-895.

Griliches, Z. (1979). Issues in Assessing the Contribution of R\&D to Productivity Growth. Bell Journal of Economics, 10(1): 92-116.

- (1992). The Search of $R \& D$ Spillovers. Scandinavian Journal of Economics, 94(Supplement): S29-47.

Grossman, G. M. And Helpman, E. (1991). Innovation and Growth in the Global Economy. MIT Press, Cambridge, MA. 
Guellec, D. And van Pottelsberghe, B. (2004). From R\&D to Productivity Growth: Do the Institutional Settings and the Source of Funds of R\&D matter? Oxford Bulletin of Economics and Statistics, 66(3): 353-378.

Hall, B. H., Jaffe, A. B. And Trajtenberg, M. (2001). The NBER Citations Data File: Lessons, Insights and Methodological Tools. NBER Working papers 8498.

InklaAR, R., TIMmer, M. P. AND VAn ARK, B. (2008). Market Services Productivity across Europe and the US. Economic Policy, 23(1): 139-194.

Jorgenson, D. W. (2005). Accounting for Growth in the Information Age. In Handbook of Economic Growth (edited by AGHION, P. AND DURLAUF, S.), ch. 10. Elsevier, Amsterdam.

Kao, C. And Chiang, M.-H. (2000). On the Estimation and Inference of a Cointegrated Regression in Panel Data. In Nonstationary Panels, Panel Cointegration, and Dynamic Panels, Advances in Econometrics (edited by BALTAGI, B. H.), ch. 15, pp. 179-222. JAI Press, Amsterdam.

Keller, W. (1998). Are International R\&D Spillovers Trade-Related? Analyzing Spillovers among Randomly Matched Trade Partners. European Economic Review, 42(8): 1469-1481.

— (2002a). Trade and the Transmission of Technology. Journal of Economic Growth, 7(1): 5-24.

- (2002b). Geographic Localization of International Technology Diffusion. American Economic Review, 92(1): 120-142.

— (2004). International Technology Diffusion. Journal of Economic Literature, XLII: 752-784.

Krusell, P. (1998). Investment-Specific R\&D and the Decline in the Relative Price of Capital. Journal of Economic Growth, 3: 131-141.

LEE, G. (2005). Direct versus Indirect International R\&D Spillovers. Information Economics and Policy, 17(3): 334-348.

- (2006). The Effectiveness of International Knowledge Spillover Channels. European Economic Review, 50(8): 2075-2088.

- (2008). International Knowledge Spillovers through the Import of Information Technology Commodities. Applied Economics, forthcoming.

Lichtenberg, F. R. And VAn Pottelsberghe, B. (1998). International R\&D Spillovers: A Comment. European Economic Review, 42(8): 1483-1491.

Lumenga-Neso, O., Olarreaga, M. And Schiff, M. (2005). On 'Indirect' Trade-Related $R \& D$ Spillovers. European Economic Review, 49(7): 1785-98.

Madden, G. And SAVAge, S. J. (2000). R\&D Spillovers, Information Technology and Telecommunications, and Productivity in ASIA and the OECD. Information Economics and Policy, 12(4): 367-392.

MADSEn, J. B. (2007). Technology Spillover through Trade and TFP Convergence: 135 years of Evidence for the OECD Countries. Journal of International Economics, 72(2): 464-480. 
- (2008). Economic Growth, TFP Convergence and the World Export of Ideas: A Century of Evidence. Scandinavian Journal of Economics, 110(1): 145-167.

MARK, N. AND Sul, D. (2003). Cointegration Vector Estimation by Panel DOLS and Long-Run Money Demand. Oxford Bulletin of Economics and Statistics, 65(5): 655-680.

Matteucci, N. And Sterlacchini, A. (2004). ICT, R\&D and Productivity Growth: Evidence from Italian Manufacturing Firms. EPKE Working Paper No. 28.

Mendi, P. (2007). Trade in Disembodied Technology and Total Factor Productivity in OECD Countries. Research Policy, 36(1): 121-133.

Ngai, R. And Samaniego, R. (2008). Research and Productivity Growth across Industries. Center for Economic Performance, mimeo.

OECD (2002a). ANBERD - R\&D Expenditure in Industry (ISIC Rev. 2), vol. 2002/1. OECD, Paris.

- (2002b). Frascati Manual. Proposed Standard Practice for Surveys on Research and Experimental Development, vol. 2002. OECD, Paris.

- (2002c). International Trade by Commodities Statistics (SITC Rev. 2) - Historical Series 19611990, vol. 2002/1. OECD, Paris.

- (2006a). International Trade by Commodities Statistics (SITC Rev. 2), vol. 2006/1. OECD, Paris.

— (2006b). OECD Information Technology Outlook. OECD, Paris.

— (2006c). STAN Bilateral Trade Database, vol. 2006/1. OECD, Paris.

— (2007). Main Science and Technology Indicators, vol. 2007/2. OECD, Paris.

PARK, W. G. (1995). International R\&D Spillovers and OECD Economic Growth. Economic Inquiry, 33(4): 571-591.

Pesaran, M. H. (2007). A Simple Panel Unit Test in the Presence of Cross Section Dependence. Journal of Applied Econometrics, 22(2): 265-312.

SAIKKONEN, P. (1991). Asymptotically Efficient Estimation of Cointegration Regressions. Econometric Theory, 7: 1-21.

SChreyer, P. (2002). Computer Price Index and International Growth and Productivity Comparisons. Review of Income and Wealth, 48(1): 15-31.

Shapiro, C. And VARIAn, H. R. (1999). Information Rules: A Strategic Guide to the Network Economy. Harvard Business School Press.

SHY, O. (2001). The Economics of Network Industries. Cambridge University Press.

StiRoh, K. J. (2002). Are ICT Spillovers Driving the New Economy? Review of Income and Wealth, 48(1): 33-57. 
TIMmer, M. AND VAN ARK, B. (2005). Does Information and Communication Technology drive EU-US Productivity Growth Differentials? Oxford Economic Papers, 57(4): 693-716.

Timmer, M., van Moergastel, T., Stuivenwold, E., Ypma, G., O’Mahony, M. And KAngASNIEMI, M. (2007). EU KLEMS Growth and Productivity Accounts. Part I Methodology. EUKLEMS project.

Timmer, M., Ypma, G. And VAn Ark, B. (2003). IT in the European Union: Driving Productivity Divergence? Groningen Growth and Development Centre Research Memorandum GD-67.

UlKu, H. (2007). R\&D, Innovation, and Growth: Evidence from Four Manufacturing Sectors in OECD Countries. Oxford Economic Papers, 59(3): 513-535.

van Ark, B., Melka, J., Mulder, N., Timmer, M. And Ypma, G. (2002). ICT Investments and Growth Accounts for the European Union 1980-2000. Groningen Growth and Development Centre Research Memorandum GD-56. (revised March 2003).

Venturini, F. (2007). ICT and Productivity Resurgence: A Growth Model for the Information Age. The B. E. Journal of Macroeconomics (Contributions), 7(1). Article 31.

VOURVACHAKI, E. (2006). Information and Communication Technologies in a Multi-Sector Endogenous Growth Model. LSE Centre for Economic Performance Discussion Paper No. 750, Revision November 2006.

Westerlund, J. (2005). New Simple Tests for Panel Cointegration. Econometric Reviews, 24(3): 297-316.

ZHU, L. AND JEON, B. N. (2007). International R\&d Spillovers: Trade, FDI, and Information Technology as Spillover Channels. Review of International Economics, 15(5): 955-976. 


\section{Appendix: Data sources and Methodology}

Assuming perfectly competitive markets and constant returns to scale, TFP is calculated as the residual growth of output over the income share-weighted rise of factor inputs, using the Tornqvist index formula (individual subscripts omitted):

$$
\Delta \ln T F P_{t}=\Delta \ln Y_{t}-\bar{s}_{t}^{L} \Delta \ln L_{t}-\left(1-\bar{s}_{t}^{L}-\bar{s}_{t}^{I}\right) \Delta \ln K_{t}^{N I}-\left(1-\bar{s}_{t}^{L}-\bar{s}_{t}^{N I}\right) \Delta \ln K_{t}^{I},
$$

where $\bar{s}$ is a two-year average of the inputs' income on GDP (in current prices). TFP is indexed to 100 in 2000. $Y$ is real GDP net of actual and imputed rents for housing. Non-IT capital includes detailed series on non-IT equipment, transport equipment and non-residential buildings $\left(K_{N I}\right)$. IT capital collects expenditure on computers and other office machinery, communication equipment and software $\left(K_{I}\right) . \quad L$ are hours worked. National Accounts series come from the Groningen Growth and Development Centre Total Economy Growth Accounting Database. ${ }^{23}$

Current prices series have been deflated by means of country-specific price indexes (taken from GGDC), and then converted into US GDP Power Purchasing Parities, expressed in constant dollars of 2000. Deflators for IT investment consist in the US hedonic indexes corrected for the differential in general inflation (price harmonisation). R\&D expenditure has been converted into a constant-price base through the industry deflators for value-added (from EU KLEMS database). ${ }^{24}$ For GERD, real expenses are obtained aggregating up industry series through the Tornqvist index formula (DRD ${ }^{I}, \mathrm{DRD}^{N I}$ and PRD).

R\&D expenditure, expressed in current prices, are taken from OECD Main Science and Technology Indicators and OECD ANBERD Rev. 2. Missing values have been calculated by geometrically interpolating the industry shares on GERD (or BERD); the percentages of 1980 are backwardly estimated from the values of 1981 using the average annual rate of change relative to the period 1981-91.

IT (manufacturing) sector is defined as the sum of office machinery and communication equipment (category 30 and 32, ISIC rev. 3). This classification slightly differs from the official one adopted by OECD (2006b, Annex A); among IT manufacturers, the latter also collects insulated wires (313) and scientific instruments (332 and 333), as well as such service industries trading IT goods as wholesale of machinery, equipment and supplies (5150), renting of office machinery and equipment (7123), and IT intangibles sectors like telecommunications (642) and computer services and related activities (72). Such additional categories are excluded from the analysis due to severe limitations in $R \& D$ data.

Patent applications at the European Patent Office and patent grants at the US Patent and Trademark Office are derived from OECD Main Science and Technology Indicators. For the IT sector, USPTO data are taken from NBER Patent files, which are available in STATA format at the Bronwyn Hall's homepage (release October 2006). Following the SIC concordance table, we have classified as IT patents those granted to the OTAF category n. 357 (Office computing and accounting machines) and n. 365-367 (Communication equipment and electronic components). NBER Patent data cover the period 1980-2002. See Hall et al. (2001) for details.

Capital stocks, $S^{\lambda}$, have been obtained from series on real investment or patent counts, $I^{\lambda}$, by

\footnotetext{
${ }^{23}$ www.ggdc.net; release July 2005.

${ }^{24}$ Www.euklems.net, release March, 2007.
} 
means of the permanent inventory method and geometric depreciation:

$$
S_{t}^{\lambda}=S_{t-1}^{\lambda}\left(1-\delta^{\lambda}\right)+I_{t}^{\lambda}, \quad S_{1980}^{\lambda}=I_{1980}^{\lambda} /\left(g^{\lambda}+\delta^{\lambda}\right) .
$$

$g^{\lambda}$ is the average annual growth rate of real investment (or patent counts) over the period 19802003. $\delta^{\lambda}$ is an asset-specific depreciation rate, assumed constant over time and across countries. It is fixed to 0.150 for R\&D and patent stocks. Following van Ark et al. (2002), $\delta$ amounts to 0.028 for structures, 0.191 for transport equipment, 0.132 for non-IT equipment, 0.315 for software, and 0.115 for TLC equipment. For office machinery, $\delta$ is variable, ranging from 0.222 to 0.312 ; this is done to reflect the rising weight in this category of computing equipment, which is characterized by a faster physical deterioration $(\delta=0.315)$ than the other types of IT assets (printers, photocopiers terminals, etc.). Finally, capital series are adjusted to mid-year values, $K_{t}=\left(S_{t}+S_{t-1}\right) / 2$.

Bilateral imports by industry come from OECD STAN Bilateral Trade Database 19882003; for the period 1980-1988, trade figures are available by commodity, and are taken from OECD Historical Statistics on International Trade by Commodities. Both series are expressed in current US dollars. The concordance between the commodity and industry classifications (respectively SITC rev. 2 and ISIC rev. 3) has been implemented through the Eurostat correspondence tables. $^{25}$ The following commodities have been attributed to the IT industry: cat. 75 and 72655 to Office machinery (cat. 30 ISIC rev. 3); categories 76 less 76483, 7722, 7723, 776 and 7786 to Communication equipment (cat. 32 ISIC rev. 3).

The level of human capital has been constructed as a Mincherian function, using Cohen and Soto (2007)'s data:

$$
H_{t}=e^{\phi * y s_{t}} .
$$

$y s_{t}$ is the average years of schooling for people aged 25 and over, and $\phi$ a positive parameter assumed constant across countries and over time. Cohen and Soto (2007) have developed such a measure of educational attainment for a large sample of countries using detailed census sources; such data are available since 1960 at ten-year intervals. In contrast to what occurs using other popular measures of human capital, $y s_{t}$ is found to be significant in standard growth regressions by Cohen and Soto (2007). ys $s_{t}$ is defined as the average sum of the number of schooling years attained by five-year age cohorts:

$$
y s_{t}=\sum_{g=g 1}^{G} q_{g t} y s_{g t}
$$

where $q_{g t}$ is the share of each cohort on the population aged 25 and over, and $y s_{g t}$ the corresponding school attainment $\left(g_{1}=25-29, \ldots, G=65\right.$ and over). The missing values between benchmark years have been calculated by means of the following (two-step) strategy. Firstly, we run a fixed-effect regression between $y s_{t}$ and the percentage shares of each five-year age cohort on the population aged 25 and over, using data at benchmark years $(t=1960,1970,1980,1990,2000) .{ }^{26}$ Secondly, in order to predict the value of $y s_{t}$ for intermediate years we apply the estimated coefficients to $q_{g t}$, being the latter variable available at an annual base. This method guarantees a larger variability in human capital series than a simple data interpolation (see Frantzen, 2000).

\footnotetext{
${ }^{25} \mathrm{http}$ //ec.europa.eu/eurostat/ramon/relations/.

${ }^{26}$ Demographic data are taken from EUROSTAT, Demographic and migration statistics (available at an annual base from 1960 onwards).
} 